\title{
Water Quality Index (WQI) Approach to Evaluate the Water Quality of Certain Tank Waters of Tiptur Taluk in Tumkur District, Karnataka, India
}

\author{
A.M.SHIVANNA and G.NAGENDRAPPA* \\ Department of Studies in Chemistry, Manasagangotri, University Of Mysore, Mysore-570006, India. \\ http://dx.doi.org/10.12944/CWE.10.1.22
}

(Received: December 01, 2014; Accepted: March 06, 2015)

\begin{abstract}
Evaluation of water quality using different parameters is complex and not easy to understand as it is variable by variable discussion. Water quality index is a single value indicator used to evaluate and present the water quality to the public and the related management in precise and understandable manner. Measured values of eleven physico-chemical parameters namely, $\mathrm{pH}, \mathrm{TDS}, \mathrm{TH}, \mathrm{Cl}, \mathrm{NO}_{3}-$ $, \mathrm{SO}_{4}{ }^{2-}, \mathrm{HCO}_{3}^{-}, \mathrm{Ca}^{2+}, \mathrm{Mg}^{2+}, \mathrm{Na}^{+}$and $\mathrm{K}^{+}$were used to calculate WQI of six tanks in Tiptur taluk. The study was taken up to understand the impact of agriculture run off from the respective catchment area, domestic sewage input and human activities which contribute to pollution load. During the investigation period from December-2010 to November-2012, it was found that the overall water quality index of the studied tanks ranged from 46.72 to 92.22 indicating the quality ranging from good quality to very poor quality. Values of variables TDS, $\mathrm{HCO}_{3}^{-}, \mathrm{Na}^{+}$and $\mathrm{K}^{+}$exceeded their desirable limits of BIS/ICMR in Karadi, Halkurke and Honnavalli tanks which depend on rain water. Waters in these tanks were of moderately poor to very poor quality. Waters of Canal fed tanks were of good to moderately poor quality.
\end{abstract}

Key words: Public, water quality index, agricultural runoff, rain fed, poor quality.

\section{INTRODUCTION}

Surface water is undoubtedly not safe for drinking purposes when compared to ground water and therefore ground water is the main source of drinking water in rural areas and many urban areas as well. Even though surface water bodies are not direct sources of drinking water for humans, they have indirect impact on the quality and availability of ground water. Tanks are the sources for domestic and agricultural use in addition to recharging the ground water. Therefore, if the quality of tank water is not properly maintained at the desired levels, the polluted water will percolate and recharge the ground water which will result in the qualitative degradation of ground water'. Tanks are also the major water sources for livestock maintenance which forms the backbone of village economy. Moreover, compatibility between water and soil is very essential and if not, properties of soil will be affected resulting in decreased agricultural productivity ${ }^{2}$. Therefore, quality of water used for irrigation should be thoroughly assessed. In this context, quality of waters of six tanks in Tiptur taluk, which is a semi arid place, was evaluated using water quality index approach.

Water quality is a measure of its suitability for human consumption, irrigation and other purposes. Water quality of surface water and in turn ground water is affected directly or indirectly by the leachates from farm fields, discharge of domestic wastes, washing of animals and cloths and also decaying of flora in the water body. 
Unsafe drinking water accounts for about $30 \%$ of mortality and $50 \%$ of morbidity to water borne infectious diseases due to improper management and environmental degradation. Hence, there is a need for continuous and periodical monitoring and understanding of water quality to make appropriate preventive and remedial measures ${ }^{3}$. In the past decades, people have neglected surface water bodies and hence these invaluable water resources are depleting at a faster rate than ever and creating a crisis of fresh water.

An integral part of any environmental monitoring program is the reporting of results to both managers and the general public. This poses a particular problem in the case of water quality monitoring because of the complexity associated with analyzing a large number of measured variables. The traditional practice has been to produce reports describing trends and compliance with official guidelines or other objectives on a variable by variable basis. One possible solution to this problem is WQI. Water quality index is one of the most effective ways to communicate information on water quality trends. WQI may be defined as "a rating reflecting the composite influence of different water quality parameters on the overall quality of water"4. It tells us whether the overall quality of water bodies poses potential threat to various uses of water such as habitat for aquatic life, irrigation quality and live stock, recreation and drinking purposes.

Water quality index provides a single number that expresses overall water quality at a certain location and time, based on several water quality parameters. Water quality index turns complex water quality data into information that is understandable and used by the public and the planners. In general, water quality indices incorporate data from multiple water quality parameters into a mathematical equation that rates the health of a lake with number ${ }^{5}$.

Accurate and timely information on the quality of water is necessary to shape a sound public policy and implement the water quality improvement programs efficiently 6 .

A number of methods like NSF-WQI, CCME WQI, Nemerows Pollution Index (NPI) and weight arithmetic index method are developed from time to time and used to evaluate water quality index. In the present study, weight arithmetic index method is used to evaluate the WQI of the selected tank waters.

Among the six tanks selected for the study, Eachanur tank is used as storage tank for supplying water to Tiptur and Arasikere towns and the remaining tanks are being used for agriculture and other domestic purposes and also serving as ground water recharge sources. Use of fertilizers, pesticides, farm yard manure and human activities are the main sources of water pollution in this area.

\section{MATERIALS AND METHODS}

Water samples from the mentioned tanks were collected at an interval of 30 days from Dec-2010 to Nov-2012 in 2 litre capacity polythene containers which were acid treated and dried previously. The parameter $\mathrm{pH}$ was determined at the site using portable $\mathrm{pH}$ meter and the samples were transported to the laboratory where the other parameters TDS, $\mathrm{TH}, \mathrm{Ca}^{2+}, \mathrm{Mg}^{2+}, \mathrm{Na}^{+}, \mathrm{K}^{+}, \mathrm{Cl}^{-}, \mathrm{NO}_{3}{ }^{-}, \mathrm{SO}_{4}{ }^{2-}$ and $\mathrm{HCO}_{3}{ }^{-}$ were determined as per the standard procedures of 7 .

The specific variables, objectives, and time period used in the index could vary from region to region, depending on local conditions and issues. It is recommended that a minimum of four variables sampled at least four times be used in the calculation of index values ${ }^{9}$.

Water Quality Index (WQI) was calculated by taking 12 months average values of 11 parameters namely, $\mathrm{pH}, \mathrm{TH}, \mathrm{TDS}, \mathrm{HCO}_{3}^{-}, \mathrm{Cl}^{-}, \mathrm{NO}_{3}^{-}, \mathrm{SO}_{4}^{2-}, \mathrm{Ca}^{2+}$, $\mathrm{Mg}^{2+}, \mathrm{Na}^{+}$and $\mathrm{K}^{+}$and standard values of same parameters set for drinking water quality by ${ }^{10,11}$ standards.

It is an established fact that the more harmful a given pollutant is, the smaller is its standard permissible value recommended for drinking water. Therefore, the 'weights' for different water quality characteristics are inversely proportional to the recommended standards for the corresponding parameters. Water quality index integrates the data pool generated after calculating due "weights" to 
different parameters ${ }^{12}$.

WQI was obtained by weight arithmetic index method in four steps as given below;

1) The unit weight of $i^{\text {th }}$ parameter $\left(W_{i}\right)$ is calculated using the formula,

$$
\mathrm{W}_{\mathrm{i}}=\frac{K}{\mathrm{~J}} ;
$$

Where, $\mathrm{V}_{\mathrm{s}}$ is the recommended standard value of $\mathrm{ith}^{\text {th }}$ parameter and $\mathrm{K}$ is proportionality constant which is determined using

$$
\mathrm{K}=\sum_{i=1}^{\frac{1}{i=n} \frac{1}{b}}
$$

2) The water quality rating $\left(Q_{i}\right)$ of $i^{\text {th }}$ parameter is calculated using the formula

$\mathrm{Q}_{\mathrm{i}}=\frac{d}{W} x 100$

Where, $\mathrm{V}_{\mathrm{a}}$ is the observed/ measured value of $i^{\text {th }}$ parameter during the study,

3) The sub-index $(\mathrm{SI})_{i}$ for the $i^{\text {th }}$ parameter is given by $(S I)_{i}=\left(Q_{i} W_{i}\right)$

4) The overall Water Quality Index (WQI) can be calculated by aggregating the quality rating $Q_{i}$ or sub-indices, linearly and taking their weighted ean, i.e. $\quad \sum_{i=1}^{\frac{\sum_{i=1}(W i Q i)}{i=n} W i}$ or $\sum_{i=1}^{\frac{\sum_{i=1}(\mathbb{S}) i}{i=n} W i} \ldots$ Brown's ${ }^{[13]}$ equation.

The overall WQI value obtained is compared with WQI range to assess the quality of water.

\section{RESULTS AND DISCUSSION}

Water quality index of the tanks is established from eleven physico-chemical parameters. The results of study are given in table-2 - table-7.

$\mathrm{pH}$

$\mathrm{pH}$ is one of the most important factors which serves as an index of the pollution. During 2010-11 and 2011-12 study period, $\mathrm{pH}$ of water recorded in the studied tanks ranged, respectively, from 6.28 to 7.40 and 6.20 to 8.21 in Eachanur tank;
6.19 to 7.80 and 6.15 to 7.74 in V. Mallenahalli tank; 6.57 to 8.31 and 7.21 to 8.70 in Karadi tank; 7.63 to 8.31 and 7.29 to 8.01 in Halkurke tank; 6.78 to 8.3 and 7.13 to 8.2 in Honnavalli tank; 6.43 to 7.89 and 6.54 to 7.42 in Albur tank. Average pH of all the samples was within the desirable limit of BIS.

\section{TDS}

It is an important parameter for drinking water and other purposes. Water containing high TDS is of inferior palatability and may produce unfavourable physiological reaction in the transient consumer $^{14}$. In the study TDS ranged from 96.0 to $173.0 \mathrm{mg} / \mathrm{L}$ and 62.0 to $171.0 \mathrm{mg} / \mathrm{L}$ in Eachanur tank water; 70.0 to $159.0 \mathrm{mg} / \mathrm{L}$ and 59.0 to $212.0 \mathrm{mg} / \mathrm{L}$ in V. Mallenahalli tank water; 282.0 to $399.0 \mathrm{mg} / \mathrm{L}$ and 378.0 to $862.0 \mathrm{mg} / \mathrm{L}$ in Karadi tank water; 331.0 to $470.0 \mathrm{mg} / \mathrm{L}$ and 461.0 to $1022.0 \mathrm{mg} / \mathrm{L}$ in Halkurke tank water; 366.0 to $488.0 \mathrm{mg} / \mathrm{L}$ and 468.0 to $1067.0 \mathrm{mg} / \mathrm{L}$ in Honnavalli tank water; 180.0 to $391.0 \mathrm{mg} / \mathrm{L}$ and 132.0 to $266.0 \mathrm{mg} / \mathrm{L}$ in Albur tank water respectively during 2010-11 and 2011-12 periods. TDS values of Eachanur, V. Mallenahalli and Albur tank waters was well within the desirable limit of $500 \mathrm{mg} / \mathrm{L}$. Waters of Karadi, Halkurke and Honnavalli tanks had TDS within the desirable range during 2010-11 period but exceeded the limit during 2011-12.

\section{Total Hardness (TH)}

Hardness of water is a measure of the capacity of water to produce lather with soap, hard water causes some problems in digestive system and the possibility of forming calcium oxalate crystals in urinary track has been found ${ }^{15}$. In the present investigation, $\mathrm{TH}$ values of tank waters ranged from 52.0 to $118.0 \mathrm{mg} / \mathrm{L}$ and 42.0 to $130.0 \mathrm{mg} / \mathrm{L}$ in Eachanur tank; 41.0 to $72.0 \mathrm{mg} / \mathrm{L}$ and 37.0 to $98.0 \mathrm{mg} / \mathrm{L}$ in V. Mallenahalli tank; 92.0 to $150.0 \mathrm{mg} / \mathrm{L}$ and 84.0 to $170.0 \mathrm{mg} / \mathrm{L}$ in Karadi tank; 66.0 to $100.0 \mathrm{mg} / \mathrm{L}$ and 80.0 to $114.0 \mathrm{mg} / \mathrm{L}$ in Halkurke tank; 110.0 to $155.0 \mathrm{mg} / \mathrm{L}$ and 114.0 to $149.0 \mathrm{mg} / \mathrm{L}$ in Honnavalli tank; 70.0 to $157.0 \mathrm{mg} / \mathrm{L}$ and 92.0 to $146.0 \mathrm{mg} / \mathrm{L}$ in Albur tank; respectively during 2010 110and 2011-12 study period. None of the samples exceeded the hardness limit of $300 \mathrm{mg} / \mathrm{L}$.

\section{Chloride}

Chloride occurs in all types of natural waters and it imparts salty taste to water. The high concentration of chloride is an indication of pollution 
due to organic waste of animal origin ${ }^{16}$. Chloride values ranged from 7.0 to $56.7 \mathrm{mg} / \mathrm{L}$ and 6.0 to $28.0 \mathrm{mg} / \mathrm{L}$ in Eachanur tank; 5.0 to $21.3 \mathrm{mg} / \mathrm{L}$ and 4.3 to $18.5 \mathrm{mg} / \mathrm{L}$ in V. Mallenahalli tank; 15.0 to $56.0 \mathrm{mg} / \mathrm{L}$ and 35.0 to $67.0 \mathrm{mg} / \mathrm{L}$ in Karadi tank;29.8to $63.8 \mathrm{mg} / \mathrm{L}$ and 46.0 to $106.0 \mathrm{mg} / \mathrm{L}$ in Halkurke tank; 17.0 to $35.5 \mathrm{mg} / \mathrm{L}$ and 34.0 to $59.0 \mathrm{mg} / \mathrm{L}$ in Honnavalli tank; 15.0 to $60.2 \mathrm{mg} / \mathrm{L}$ to 17.0 to $40.0 \mathrm{mg} / \mathrm{L}$ in Albur tank respectively during $2010-11$ and $2011-12$ period. In all the samples chloride concentration was below the standard value of $250 \mathrm{mg} / \mathrm{L}$.

\section{Nitrate}

Nitrate is the most important nutrient in the ecosystem. Nitrates are of prime concern because of methamoglobinemia when concentration exceeds $40 \mathrm{mg} / \mathrm{L}$. In cattle, the high concentration of nitrates causes more mortality in pigs and calves and abortion in brood animals ${ }^{8}$. Nitrate values ranged from 0.08 to $0.83 \mathrm{mg} / \mathrm{L}$ and 0.21 to $0.63 \mathrm{mg} / \mathrm{L}$ in Eachanur tank; 0.90 to $2.2 \mathrm{mg} / \mathrm{L}$ and 0.95 to $1.87 \mathrm{mg} / \mathrm{L}$ in V. Mallenahalli tank; 1.30 to $3.24 \mathrm{mg} / \mathrm{L}$ and 1.0 to $2.22 \mathrm{mg} / \mathrm{L}$ in Karadi tank; 1.8 to $3.2 \mathrm{mg} / \mathrm{L}$ and 1.9 to $3.2 \mathrm{mg} / \mathrm{L}$ in Halkurke tank; 0.96 to $2.62 \mathrm{mg} / \mathrm{L}$ and 0.96 to $2.62 \mathrm{mg} / \mathrm{L}$ in Honnavalli tank; 0.16 to $0.35 \mathrm{mg} / \mathrm{L}$ and 0.16 to $0.35 \mathrm{mg} / \mathrm{L}$ in Albur tank water during 2010-11 and 2011-12 respectively. In all the samples nitrate concentration was within the required level of $45 \mathrm{mg} / \mathrm{L}$. Generally water bodies polluted by organic matter exhibit higher values of nitrate ${ }^{[5]}$ and accordingly the above water bodies are not organically polluted.

\section{Sulphate}

Sulphate ion is an important constituent of hardness with calcium and magnesium. It produces an objectionable taste at $300-400 \mathrm{mg} / \mathrm{L}$, is laxative at concentrations around $1000 \mathrm{mg} / \mathrm{L}{ }^{[16]}$ and with sodium it interferes with the normal functioning of the intestine. Sulphate values ranged from 3.3 to $15.0 \mathrm{mg} / \mathrm{L}$ and 8.0 to $14.0 \mathrm{mg} / \mathrm{L}$ in Eachanur tank; 3.3 to $20.0 \mathrm{mg} / \mathrm{L}$ and 7.0 to $16.0 \mathrm{mg} / \mathrm{L}$ in $\mathrm{V}$. Mallenahalli

Table 1: Drinking water standards used for calculating WQI

\begin{tabular}{lccccccccccr}
\hline Parameters & pH & TDS & TH & $\mathrm{Cl}$ & $\mathrm{NO}_{3}$ & $\mathrm{SO}_{4}$ & $\mathrm{HCO}_{3}$ & $\mathrm{Ca}$ & $\mathrm{Mg}$ & $\mathrm{Na}$ & $\mathrm{K}$ \\
\hline $\mathrm{BIS}(1991) / \operatorname{ICMR}(1975)$ & $6.5-8.5$ & 500 & 300 & 250 & 45 & 200 & 244 & 75 & 30 & 20 & 10 \\
\hline
\end{tabular}

All parameters, except $\mathrm{pH}$, are expressed in $\mathrm{mg} / \mathrm{L}$.

Table 2: WQI of Eachanur tank water during the study period $(K=2.7)$

\begin{tabular}{|c|c|c|c|c|c|c|c|c|}
\hline \multirow[b]{2}{*}{$\begin{array}{l}\text { Chemical } \\
\text { Parameter }\end{array}$} & \multicolumn{4}{|c|}{ 2010-11 } & \multicolumn{4}{|c|}{$2011-12$} \\
\hline & $\mathbf{V}_{\mathrm{a}}$ & $Q_{i}$ & $w_{i}$ & $\overline{(\mathrm{SI})_{\mathrm{i}}}$ & $V_{a}$ & $Q_{i}$ & $w_{i}$ & $(\mathrm{SI})_{\mathrm{i}}$ \\
\hline $\mathrm{pH}$ & 6.65 & 88.66 & 0.36 & 31.92 & 6.78 & 90.4 & 0.36 & 32.54 \\
\hline TDS & 140.17 & 28.03 & 0.005 & 0.14 & 122.9 & 24.58 & 0.005 & 0.132 \\
\hline $\mathrm{TH}$ & 82.83 & 27.61 & 0.009 & 0.25 & 89.75 & 29.9 & 0.009 & 0.269 \\
\hline $\mathrm{Ca}^{2+}$ & 18.1 & 24.13 & 0.036 & 0.87 & 19.3 & 25.73 & 0.036 & 0.926 \\
\hline $\mathrm{Mg}^{2+}$ & 8.0 & 26.7 & 0.09 & 2.40 & 10.3 & 34.33 & 0.09 & 3.09 \\
\hline $\mathrm{Cl}^{-}$ & 63.0 & 25.2 & 0.01 & 0.252 & 16.3 & 6.52 & 0.01 & 0.07 \\
\hline $\mathrm{NO}_{3}{ }^{-}$ & 0.49 & 1.09 & 0.06 & 0.065 & 0.40 & 0.89 & 0.06 & 0.055 \\
\hline $\mathrm{SO}_{4}^{2-}$ & 10.0 & 5.0 & 0.013 & 0.065 & 10.6 & 5.3 & 0.013 & 0.07 \\
\hline $\mathrm{HCO}_{3}^{-}$ & 76.0 & 31.1 & 0.011 & 0.342 & 80.5 & 33.0 & 0.011 & 0.36 \\
\hline $\mathrm{Na}^{+}$ & 17.9 & 89.5 & 0.135 & 12.08 & 11.7 & 58.5 & 0.135 & 0.79 \\
\hline $\mathrm{K}^{+}$ & 3.8 & 37.8 & 0.27 & 10.21 & 3.1 & 31.0 & 0.27 & 8.37 \\
\hline & & $\Sigma W_{i}=0.999$ & & $\begin{array}{l}\Sigma(\mathrm{SI})_{i}=58.59 \\
W Q I=58.65\end{array}$ & & $\Sigma W_{i}=0.999$ & & $\begin{array}{l}\Sigma(\mathrm{SI})_{\mathrm{i}}=46.67 \\
W Q \mathrm{I}=46.72\end{array}$ \\
\hline
\end{tabular}


tank; 5.2 to $30.0 \mathrm{mg} / \mathrm{L}$ and 14.0 to $40.0 \mathrm{mg} / \mathrm{L}$ in Karadi tank; 10.0 to $32.0 \mathrm{mg} / \mathrm{L}$ and 28.0 to $43.0 \mathrm{mg} / \mathrm{L}$ in Halkurke tank; 5.6 to $30.0 \mathrm{mg} / \mathrm{L}$ and 13.0 to $28.0 \mathrm{mg} / \mathrm{L}$ in Honnavalli tank; 0.0 to $30.0 \mathrm{mg} / \mathrm{L}$ and 11.0 to $22.0 \mathrm{mg} / \mathrm{L}$ in Albur tank waters during 2010-11 and 2011-12 respectively. In all the samples sulphate concentration was within the desirable limit of 200mg/L.

\section{Bicarbonate}

Concentration of bicarbonate was in the range of 30.0 to $100.0 \mathrm{mg} / \mathrm{L}$ and 40.0 to $102.0 \mathrm{mg} / \mathrm{L}$ in Eachanur tank; 42.0 to $99.0 \mathrm{mg} / \mathrm{L}$ and 40.0 to $85.0 \mathrm{mg} / \mathrm{L}$ in V. Mallenahalli tank; 140.0 to $260.0 \mathrm{mg} / \mathrm{L}$ and 230.0 to $400.0 \mathrm{mg} / \mathrm{L}$ in Karadi tank; 151.0 to $422.0 \mathrm{mg} / \mathrm{L}$ and 200.0 to $360.0 \mathrm{mg} / \mathrm{L}$ in Halkurke tank; 200.0 to $301.0 \mathrm{mg} / \mathrm{L}$ and 300.0 to $450.0 \mathrm{mg} / \mathrm{L}$

Table 3: WQI of V. Mallenahalli tank water during the study period ( $K=2.7)$

\begin{tabular}{|c|c|c|c|c|c|c|c|c|}
\hline \multirow[b]{2}{*}{$\begin{array}{l}\text { Chemical } \\
\text { Parameter }\end{array}$} & \multicolumn{4}{|c|}{ 2010-11 } & \multicolumn{4}{|c|}{ 2011-12 } \\
\hline & Va & Qi & $\mathbf{W i}$ & (SI) & Va & Qi & Wi ( & (SI)i \\
\hline $\mathrm{pH}$ & 6.87 & 91.6 & 0.36 & 32.98 & 6.79 & 90.53 & 0.36 & 32.59 \\
\hline TDS & 107.3 & 21.5 & 0.005 & 0.116 & 118.67 & 23.73 & 0.005 & 0.128 \\
\hline $\mathrm{TH}$ & 56.5 & 18.8 & 0.009 & 0.169 & 61.1 & 20.36 & 0.009 & 0.183 \\
\hline $\mathrm{Ca} 2+$ & 12.83 & 17.1 & 0.036 & 0.616 & 13.7 & 18.27 & 0.036 & 0.658 \\
\hline Mg2+ & 5.52 & 18.4 & 0.09 & 1.66 & 6.7 & 22.33 & 0.09 & 2.10 \\
\hline Cl- & 12.44 & 5.0 & 0.01 & 0.055 & 12.1 & 4.84 & 0.01 & 0.053 \\
\hline NO3- & 1.49 & 3.31 & 0.06 & 0.199 & 1.34 & 2.98 & 0.06 & 0.179 \\
\hline SO42- & 11.92 & 5.96 & 0.013 & 0.077 & 11.0 & 5.50 & 0.013 & 0.07 \\
\hline HCO3- & 68.9 & 28.2 & 0.011 & 0.311 & 68.33 & 28.00 & 0.011 & 0.308 \\
\hline $\mathrm{Na}+$ & 18.5 & 91.0 & 0.135 & 1.23 & 12.6 & 0.011 & 0.135 & 0.85 \\
\hline \multirow[t]{2}{*}{$\mathrm{K}_{+}$} & 3.73 & 37.3 & 0.27 & 10.1 & 5.0 & 0.308 & 0.27 & 13.5 \\
\hline & & \multicolumn{4}{|c|}{$\begin{array}{r}\Sigma \mathrm{Wi}=0.999 \Sigma(\mathrm{SI}) \mathrm{i}=47.84 \\
\mathrm{WQI}=47.89\end{array}$} & $\Sigma \mathrm{Wi}=0.999$ & \multicolumn{2}{|c|}{$\begin{array}{l}\Sigma(\mathrm{SI}) \mathrm{i}=50.62 \\
\mathrm{WQI}=50.67\end{array}$} \\
\hline
\end{tabular}

Table 4: WQI of Karadi tank water during the study period $(K=2.7)$

\begin{tabular}{|c|c|c|c|c|c|c|c|c|}
\hline \multirow[b]{2}{*}{$\begin{array}{l}\text { Chemical } \\
\text { Parameter }\end{array}$} & \multicolumn{4}{|c|}{ 2010-11 } & \multicolumn{4}{|c|}{ 2011-12 } \\
\hline & $\mathrm{Va}$ & Qi & Wi & (SI)i & Va & Qi & $\mathbf{W i}$ & (SI)i \\
\hline $\mathrm{pH}$ & 7.44 & 99.2 & 0.36 & 35.71 & 7.61 & 101.5 & 0.36 & 36.53 \\
\hline TDS & 364.5 & 72.9 & 0.005 & 0.39 & 487.5 & 97.5 & 0.005 & 0.53 \\
\hline $\mathrm{TH}$ & 127.1 & 42.37 & 0.009 & 0.38 & 132.42 & 44.14 & 0.009 & 0.397 \\
\hline $\mathrm{Ca} 2+$ & 34.23 & 45.64 & 0.036 & 1.64 & 24.9 & 33.2 & 0.036 & 1.19 \\
\hline $\mathrm{Mg} 2+$ & 10.13 & 33.77 & 0.09 & 3.04 & 17.3 & 57.67 & 0.09 & 5.19 \\
\hline $\mathrm{Cl}-$ & 37.13 & 14.85 & 0.01 & 0.163 & 52.33 & 20.93 & 0.01 & 0.23 \\
\hline NO3- & 2.21 & 4.91 & 0.06 & 0.29 & 1.74 & 3.87 & 0.06 & 0.23 \\
\hline SO42- & 18.1 & 9.05 & 0.013 & 0.118 & 26.8 & 13.4 & 0.013 & 0.174 \\
\hline HCO3- & 206.25 & 84.53 & 0.011 & 0.93 & 330.1 & 135.24 & 0.011 & 1.49 \\
\hline $\mathrm{Na}+$ & 69.6 & 348.0 & 0.135 & 4.69 & 121.0 & 605.0 & 0.135 & 8.17 \\
\hline \multirow[t]{3}{*}{$\mathrm{K}+$} & 7.71 & 77.1 & 0.27 & 20.8 & 11.5 & 115.0 & 0.27 & 31.05 \\
\hline & & $\Sigma \mathrm{Wi}=0.999$ & & $\Sigma(\mathrm{SI}) \mathrm{i}=68.17$ & & $\Sigma \mathrm{Wi}=0.999$ & \multicolumn{2}{|c|}{$\Sigma(\mathrm{SI}) \mathrm{i}=85.18$} \\
\hline & & & & WQI = 68.24 & & & \multicolumn{2}{|c|}{ WQI = 85.26} \\
\hline
\end{tabular}


in Honnavalli tank; 100.0 to $214.0 \mathrm{mg} / \mathrm{L}$ and 125.0 to $186.0 \mathrm{mg} / \mathrm{L}$ in Albur tank waters during the study period 2010-11 and 2011-12 respectively. Bicarbonate value was within the desirable limit of $244 \mathrm{mg} / \mathrm{L}$ in Eachanur, V. Mallenahalli and Albur tank waters. Its average value exceeded acceptable limit of $244 \mathrm{mg} / \mathrm{L}$ in the remaining tank waters.

\section{Calcium}

Calcium is one of the important nutrients for organisms and as such has no hazardous effect on human health. Depending on the type of rocks, its quantity in natural waters varies from 10 to $100 \mathrm{mg} / \mathrm{L}$. In the present investigation, calcium ranged from 8.0 to $23.6 \mathrm{mg} / \mathrm{L}$ and 7.0 to $28.0 \mathrm{mg} / \mathrm{L}$ in

Table 5: WQI of Halkurke tank water during the study period $(K=2.7)$

\begin{tabular}{|c|c|c|c|c|c|c|c|c|}
\hline \multirow[b]{2}{*}{$\begin{array}{l}\text { Chemical } \\
\text { Parameter }\end{array}$} & \multicolumn{4}{|c|}{ 2010-11 } & \multicolumn{4}{|c|}{ 2011-12 } \\
\hline & Va & $\mathbf{Q i}$ & Wi & (SI)i & $\mathrm{Va}$ & Qi & Wi & (SI)i \\
\hline $\mathrm{pH}$ & 7.95 & 106.0 & 0.36 & 38.16 & 7.72 & 102.9 & 0.36 & 34.05 \\
\hline TDS & 417.2 & 83.43 & 0.005 & 0.45 & 733.0 & 146.6 & 0.005 & 0.79 \\
\hline $\mathrm{TH}$ & 83.92 & 27.97 & 0.009 & 0.25 & 92.33 & 30.78 & 0.009 & 0.277 \\
\hline $\mathrm{Ca} 2+$ & 16.47 & 21.96 & 0.036 & 0.79 & 18.3 & 24.4 & 0.036 & 0.878 \\
\hline $\mathrm{Mg} 2+$ & 10.39 & 34.63 & 0.09 & 3.12 & 11.7 & 39.0 & 0.09 & 3.51 \\
\hline $\mathrm{Cl}-$ & 46.0 & 18.4 & 0.01 & 0.20 & 68.2 & 27.28 & 0.01 & 0.30 \\
\hline NO3- & 2.42 & 5.37 & 0.06 & 0.32 & 2.38 & 5.29 & 0.06 & 0.32 \\
\hline SO42- & 23.8 & 11.9 & 0.013 & 0.154 & 35.2 & 17.6 & 0.013 & 0.23 \\
\hline HCO3- & 247.33 & 101.36 & 0.011 & 1.11 & 288.9 & 118.4 & 0.011 & 1.30 \\
\hline $\mathrm{Na}+$ & 96.4 & 482.0 & 0.135 & 6.5 & 193.4 & 967.0 & 0.135 & 13.05 \\
\hline \multirow[t]{3}{*}{$\mathrm{K}_{+}$} & 8.79 & 87.9 & 0.27 & 23.7 & 12.75 & 127.5 & 0.27 & 34.42 \\
\hline & & \multirow{2}{*}{$\Sigma W i=0.999$} & & \multirow{2}{*}{$\begin{array}{l}\Sigma(\mathrm{SI}) \mathrm{i}=74.79 \\
W Q \mathrm{~W}=74.86\end{array}$} & & \multirow[t]{2}{*}{$\Sigma \mathrm{Wi}=0.999$} & & $(\mathrm{SI}) \mathrm{i}=92.13$ \\
\hline & & & & & & & & $|\mathrm{Q}|=92.22$ \\
\hline
\end{tabular}

Table 6: WQI of Honnavalli tank water during the study period $(K=2.7)$

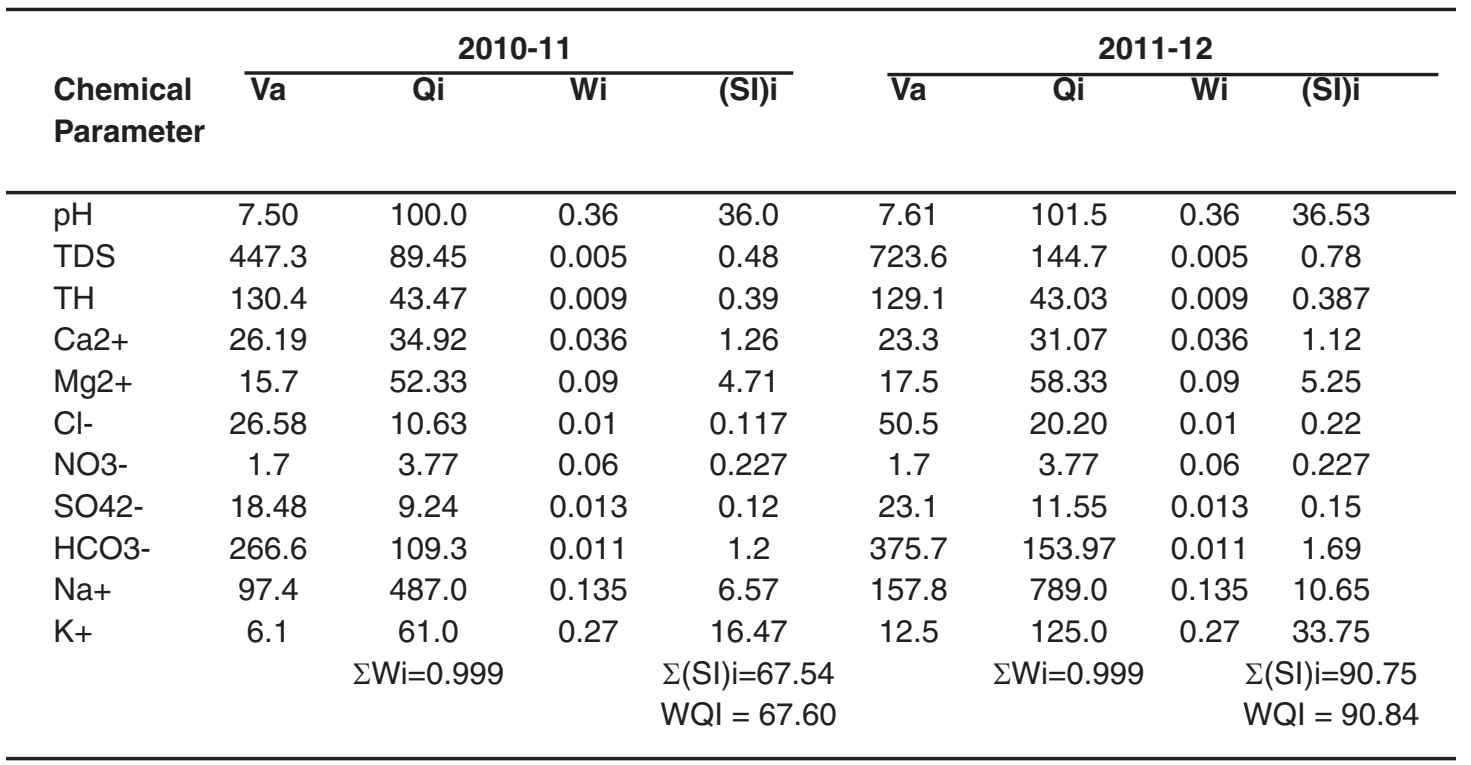


Eachanur tank; 6.4 to $17.3 \mathrm{mg} / \mathrm{L}$ and 6.0 to $20.0 \mathrm{mg} / \mathrm{L}$ in V. Mallenahalli tank; 26.0 to $43.0 \mathrm{mg} / \mathrm{L}$ and 19.0 to $34.0 \mathrm{mg} / \mathrm{L}$ in Karadi tank; 10.8 to $29.6 \mathrm{mg} / \mathrm{L}$ and 15.0 to $23.0 \mathrm{mg} / \mathrm{L}$ in Halkurke tank; 18.8 to $38.5 \mathrm{mg} / \mathrm{L}$ and 18.0 to $38.0 \mathrm{mg} / \mathrm{L}$ in Honnavalli tank; 12.8 to $32.5 \mathrm{mg} / \mathrm{L}$ and 15.0 to $27.0 \mathrm{mg} / \mathrm{L}$ in Albur tank waters during the study period of 2010-11 and 2011-12 respectively and all the samples contain calcium below the desirable limit of $75 \mathrm{mg} / \mathrm{L}$.

\section{Magnesium}

Magnesium occurs in all kinds of natural waters with calcium, but its concentration is generally lower than calcium concentration. Concentration $>500 \mathrm{mg} / \mathrm{L}$ impart unpleasant taste to water making it unpalatable. High concentration combined with sulphate acts as laxative to human beings. In the present study, magnesium ranged from 4.1 to $14.3 \mathrm{mg} / \mathrm{L}$ and 6.0 to $14.6 \mathrm{mg} / \mathrm{L}$ in Eachanur tank; 3.0 to $9.7 \mathrm{mg} / \mathrm{L}$ and 2.6 to $11.7 \mathrm{mg} / \mathrm{L}$ in V. Mallenahalli tank; 6.15 to $15.0 \mathrm{mg} / \mathrm{L}$ and 9.0 to $24.0 \mathrm{mg} / \mathrm{L}$ in
Karadi tank; 3.9 to $12.2 \mathrm{mg} / \mathrm{L}$ and 9.0 to $14.0 \mathrm{mg} / \mathrm{L}$ in Halkurke tank; 12.6 to $18.7 \mathrm{mg} / \mathrm{L}$ and 15.0 to $22.0 \mathrm{mg} / \mathrm{L}$ in Honnavalli tank; 7.3 to $21.4 \mathrm{mg} / \mathrm{L}$ and 12.0 to $20.0 \mathrm{mg} / \mathrm{L}$ in Albur tank waters and in all the samples its content was within $30 \mathrm{mg} / \mathrm{L}$.

\section{Sodium}

Sodium is one of the important cations occurring in natural waters and is derived from weathering of rocks. Domestic sewage and industrial wastes are rich in sodium. Sodium varied from 0.4 to $31.5 \mathrm{mg} / \mathrm{L}$ and 8.0 to $14.5 \mathrm{mg} / \mathrm{L}$ in Eachanur tank; 0.4 to $39.0 \mathrm{mg} / \mathrm{L}$ and 3.0 to $16.0 \mathrm{mg} / \mathrm{L}$ in $\mathrm{V}$. Mallenahalli tank and it was within the desirable limit of $20 \mathrm{mg} / \mathrm{L}$. At lower concentrations there are no adverse effects on the health. Sodium varied from 2.2 to $92.5 \mathrm{mg} / \mathrm{L}$ and 76.0 to $160.0 \mathrm{mg} / \mathrm{L}$ in Karadi tank; 4.3 to $130.0 \mathrm{mg} / \mathrm{L}$ and 120.0 to $271.0 \mathrm{mg} / \mathrm{L}$ in Halkurke tank; 3.9 to $122.0 \mathrm{mg} / \mathrm{L}$ and 120.0 to $200.0 \mathrm{mg} / \mathrm{L}$ in Honnavalli tank; 6.5 to $102.0 \mathrm{mg} / \mathrm{L}$ and 36.0 to $63.0 \mathrm{mg} / \mathrm{L}$ in Albur tank waters respectively during 2010-11 and 2011-

Table 7: WQI of Albur tank water during the study period $(K=2.7)$

\begin{tabular}{|c|c|c|c|c|c|c|c|c|}
\hline \multirow{2}{*}{$\begin{array}{l}\text { Chemical } \\
\text { Parameter }\end{array}$} & \multicolumn{4}{|c|}{$2010-11$} & \multicolumn{4}{|c|}{ 2011-12 } \\
\hline & $\mathrm{Va}$ & Qi & Wi & (SI)i & $\mathrm{Va}$ & Qi & Wi & (SI)i \\
\hline $\mathrm{pH}$ & 7.18 & 95.73 & 0.36 & 34.46 & 6.83 & 91.06 & 0.36 & 32.78 \\
\hline TDS & 271.3 & 54.27 & 0.005 & 0.29 & 234.5 & 46.9 & 0.005 & 0.25 \\
\hline $\mathrm{TH}$ & 95.0 & 31.67 & 0.009 & 0.28 & 119.4 & 39.8 & 0.009 & 0.358 \\
\hline Ca2+ & 18.27 & 24.36 & 0.036 & 0.88 & 21.3 & 28.4 & 0.036 & 1.02 \\
\hline $\mathrm{Mg} 2+$ & 12.02 & 40.07 & 0.09 & 3.6 & 16.3 & 54.33 & 0.09 & 4.89 \\
\hline $\mathrm{Cl}-$ & 33.33 & 13.33 & 0.01 & 0.147 & 27.3 & 10.92 & 0.01 & 0.12 \\
\hline NO3- & 0.24 & 0.53 & 0.06 & 0.03 & 0.24 & 0.53 & 0.06 & 0.03 \\
\hline SO42- & 13.33 & 6.66 & 0.013 & 0.087 & 16.0 & 8.0 & 0.013 & 0.10 \\
\hline HCO3- & 144.5 & 59.22 & 0.011 & 0.65 & 151.33 & 62.0 & 0.011 & 0.68 \\
\hline $\mathrm{Na}+$ & 58.2 & 291.0 & 0.135 & 3.93 & 47.2 & 236.0 & 0.135 & 3.19 \\
\hline \multirow[t]{2}{*}{$\mathrm{K}+$} & 4.12 & 41.2 & 0.27 & 11.1 & 5.3 & 53.0 & 0.27 & 14.3 \\
\hline & & $\Sigma \mathrm{Wi}=0.999$ & & $\begin{array}{c}\Sigma(\mathrm{SI}) \mathrm{i}=55.48 \\
\mathrm{WQI}=55.53\end{array}$ & & $\Sigma W i=0.99$ & \multicolumn{2}{|c|}{$\Sigma(\mathrm{SI}) \mathrm{i}=57.73$} \\
\hline
\end{tabular}

Table 8: Water Quality Rating Based On WQI Values

\begin{tabular}{lccccc}
\hline WQI value & $\mathbf{0 - 2 5}$ & $\mathbf{2 6 - 5 0}$ & $\mathbf{5 1 - 7 5}$ & $\mathbf{7 6 - 1 0 0}$ & $>100$ \\
\hline $\begin{array}{l}\text { Water } \\
\text { quality } \\
\text { rating }\end{array}$ & Excellent & Good & $\begin{array}{c}\text { Poor } \\
\text { (moderately } \\
\text { polluted) }\end{array}$ & $\begin{array}{c}\text { Very } \\
\text { poor }\end{array}$ & $\begin{array}{l}\text { Unfit for } \\
\text { drinking }\end{array}$ \\
\hline
\end{tabular}


Table 9: Consolidated WQI values obtained for all the six tanks during the study period 2010-2012

\begin{tabular}{lcccc}
\hline $\begin{array}{l}\text { Studied } \\
\text { Tanks }\end{array}$ & $\begin{array}{c}\text { WQI during } \\
\text { 2010-11 }\end{array}$ & Quality rating & $\begin{array}{c}\text { WQI during } \\
\mathbf{2 0 1 1 - 1 2}\end{array}$ & Quality rating \\
\hline Eachanur & 58.65 & Moderately polluted & 46.72 & Good \\
V.Mallenahalli & 47.89 & Good & 50.67 & $\sim$ Good \\
Karadi & 68.24 & Moderately polluted & 85.18 & Very poor \\
Halkurke & 74.86 & Moderately polluted & 92.22 & Very poor \\
Honnavalli (Hirekere) & 67.6 & Moderately polluted & 90.84 & Very poor \\
Albur & 55.53 & Moderately polluted & 57.78 & Moderately polluted \\
\hline
\end{tabular}

12 and its concentration exceeded the desirable limit. Waters of these tanks, if used for drinking, may cause cardiovascular diseases, and in women toxemia associated with pregnancy ${ }^{17}$. When used for irrigation, sodium present in water affects soil permeability making soils to become hard to plough and unsuitable for seedling emergence ${ }^{8}$.

\section{Potassium}

Potassium is also naturally occurring element but occurs at lower concentrations than sodium, calcium and magnesium. It has similar chemistry like sodium and remains in solution without forming any precipitate. As such, it is not very much significant from the health point of view. In the present study, potassium content in the studied samples ranged from 0.06 to $8.0 \mathrm{mg} / \mathrm{L}$ and 2.0 to $5.0 \mathrm{mg} / \mathrm{L}$ in Eachanur tank; 0.06 to $7.0 \mathrm{mg} / \mathrm{L}$ and 3.0 to $10.0 \mathrm{mg} / \mathrm{L}$ in V. Mallenahalli tank; 0.2 to $10.0 \mathrm{mg} / \mathrm{L}$ and 7.0 to $16.0 \mathrm{mg} / \mathrm{L}$ in Karadi tank; 0.2 to $12.8 \mathrm{mg} / \mathrm{L}$ and 7.0 to $18.0 \mathrm{mg} / \mathrm{L}$ in Halkurke tank; 0.12 to $10.7 \mathrm{mg} / \mathrm{L}$ and 6.0 to $21.0 \mathrm{mg} / \mathrm{L}$ in Honnavalli tank; 0.1 to $10.7 \mathrm{mg} / \mathrm{L}$ and 3.0 to $8.0 \mathrm{mg} / \mathrm{L}$ in Albur tank waters respectively during 2010-11 and 2011-12 study period. Waters of Eachanur, V. Mallenahalli and Albur tanks contain magnesium within the desirable limit of $10 \mathrm{mg} / \mathrm{L}$ but waters of Karadi, Halkurke and Honnavalli tanks contain magnesium slightly above the desirable limit.

Water quality differs from time to time and its requirement varies with intended use. Thus any polluted water may be considered suitable for some of the uses but may remain unsuitable for other purposes.
The water quality is evaluated by comparing the obtained WQI values (as per tables2 -7) with water quality rating as per table-8, ${ }^{19,20,21}$.

Consolidated WQI of all studied tanks evaluated during $2010-11$ and $2011-12$ is presented in Table-9.

During the study period 2010-11, WQI of water of all the tanks ranged from 47.89 to 74.86 indicating the status of rating from good to moderately polluted state. But during the study period 2011-12, WQI ranged from 46.72 to 92.22 indicating the water quality rating from good to very poor. During two years study period, overall WQI of all the studied tank waters ranged from 46.72 to 92.22 indicating the water quality of these tanks ranging from good to very poor.

Hence, Eachanur and V. Mallenahalli tank waters can be used for drinking as their quality was found good but with proper treatment as biological index was not determined. Waters of Karadi, Halkurke, Honnavalli and Albur tanks cannot be used for drinking but can be used for irrigation with suitable treatment.

Eachanur tank water was moderately polluted during 2010-11which might be due to low level of standing water and the same water body during 2011-12 was having more of water and the pollution factors are ameliorated.

V. Mallenahalli tank water quality remains good during both the years of study as it is located a bit away from the village. 
Albur tank water quality was poor during both the years as it is situated by the side of the village and human activities are more. Also more number of vehicles run on the tank bund since Tiptur-Turuvekere road is on the bund partially which might have added more vehicular exhausts into water. Water from Hemavathy reservoir fills this tank through cascade system and water runs through fields unlike Eachanur tank which is filled by lift system from the canal of the same Hemavthy reservoir .

Rain fed tanks Karadi, Halkurke and Honnavalli tanks which were moderately polluted during the year 2010-11 which might be due to excess rain over normal rain in the study area during the year 2010. These tanks were either full or more than $80 \%$ full. But total annual rainfall was $529.5 \mathrm{~mm}$ during 2011 and 452.44mm during 2012 against normal of $613 \mathrm{~mm}$ of rain and there was draught in the taluk. Water receded in these tanks and they went almost to dry. Water quality of Karadi, Halkurke and Honnavalli ranged from moderately polluted to very poor status and using it for human consumption is ruled out. Even for direct irrigation purpose also, these waters are not safe due to high sodium content. Bicarbonate content and TDS values were also high in these waters. In agricultural areas, rain water will have higher concentration of chemicals due to fertilizer and pesticide residues in the atmosphere and runoff water from the catchment area, input materials containing minerals, their solubility and chemical equilibrium prevailing in the water bodies ${ }^{22}$. Albur tank water was in moderately polluted state as its WQI value was in 51-75range throughout the study period.

\section{REFERENCES}

1. A.M.Shivanna and G.Nagendrappa, Nature Environment and Pollution Technology, 11 (4); 535-540 (2012).

2. A.M.Shivanna and G.Nagendrappa, IOSR journal of Applied Chemistry, 7(11), Ver.1; 01-05 (2014).

3. Vijayabhaskar C, Ph.D thesis submitted to University of Mysore, Mysore, (2010).

4. Dhirendra Mohan Joshi, Alok Kumar and Namita Agrawal, RASAYAN J. Chem, 2(1); 195-203 (2009).

5. Thakor F.J, Bhoj D.K, Dabhi H.R, Pandya S.N and Nikitaraj B.Chauhan, Current world environment, 6(2); 225-231 (2011).

6. Mishra, P and R.K. Patel, Ph.D thesis submitted to Roorkela University, (2005).

7. APHA AWWA WEF, Standard Methods for Examination of Water and Wastewater, 19th edition, American Public Health Association, Washington, DC(1995).

8. Trivedy R.K. and Goel, P.K. Chemical and Biological Methods for Water Pollution Studies. Environmental Publications, Karad (1986).

9. Canadian Council of Ministers of the Environment, Canadian water quality Guidelines for the protection of Aquatic life CCME Water Quality Index 1.0, Users manual (2001).
10. Bureau of Indian Standards (BIS), Specification for drinking water, IS: 10500 , New Delhi (1991).

11. Manual of standards of quality for drinking water supplies, Indian Council of Medical Research (ICMR), New Delhi (1975).

12. Kankal N.C, Indurkar M.M, Gudadhe S.K and S.R Wate, Asian J. Exp. Sci., 26 (1); 39-48 (2012).

13. Brown, R.M., Mc Cleeland, N.I., Deininger, R.A and Tozer, R.G, Water Sewage Works, 117; 339-343 (1970).

14. Abdul Jameel. A, Indian J of Env. Health, 44; 108-112 (2002).

15. Vilas. Y. Sonawane and Anil. M. Khole, J. of Chemical and Pharmaceautical Research.,2(5); 104-107 (2010).

16. Singh, J.P and P.K Ray, Environment and Ecology, 13(2); 330-335 (1995).

17. USEPA Water quality criteria, 1972, EPA R 3/73-033, Washington D.C(1973).

18. National Academy of sciences, Drinking water and Health, Federal Register, 43 (132); 35764 (1977).

19. Chaterjee $\mathrm{C}$, and Razuddin, M, Nature Environment and Pollution Technology, 1 (2); 181-189(2002).

20. Avash Maruthi $Y$ and S.R.Rao, Asian J. of Chemistry, 16, 122 (2004). 
21. Shantilal D. Rathod, Mohammad Mohsin, Mazahar Farooqui, Asian journal of Biochemical and pharmaceutical research,
1(2); 368-372 (2011).

22. A.M.Shivanna and G.Nagendrappa, Indian journal of environmental protection, 34 (5); 392-400 (2014). 